\title{
Efficiency of the use of the active working body on the front plow
}

\author{
Sherzodkhuja Mirzakhodjaev ${ }^{1 *}$, Khodjimurod Shodiev ${ }^{1}$, Gayrat Uralov ${ }^{1}$, Sunnat Badalov ${ }^{2}$ \\ and Dilsabo Choriyeva ${ }^{2}$
}

${ }^{1}$ Samarkand Institute of veterinary medicine, Samarkand, Uzbekistan

${ }^{2}$ Karshi Engineering Economic Institute, Karshi, Uzbekistan

\begin{abstract}
This work aims to substantiate the effectiveness of the use of an active working body on a front plow. The necessity of using active working bodies is justified, and a front plow with passive and active working bodies is proposed. The efficiency of installing an active working body on a front plow is analyzed. The forces acting on the combined frontal plow are considered. The analysis of the influence of the active working body on the stability of the movement and the traction resistance of the front plow is carried out. The results of experimental studies of a frontal plow with active and passive working bodies are presented. The use of an active working body on the front plow increases the degree of soil crumbling by $8,5 \%$, reduces the traction resistance and specific fuel consumption by $14,7 \%$ and $17,2 \%$, respectively, and increases the productivity of the unit by $11,3 \%$.
\end{abstract}

\section{Introduction}

The problem of efficient use of energy-saturated wheeled tractors is more acute when they aggregate wide-reach high-speed tillage machines. When testing and operating these machines, it was found [1-23] that the power of energy-saturated wheeled tractors is used inefficiently when they are aggregated since the traction force developed by the tractors was not sufficient for working at the required speeds in all soil and climatic conditions due to their insufficient coupling weight.

As the working speeds of machines with passive working bodies increase, their resistance increases, which leads to the need to work on reduced gears with incomplete engine loading and increased skidding of the propellers. The loss of power on skidding when working with wheeled tractors is $13-17 \%$ and in some periods $30-35 \%$ [24-27]. At low speeds, the technological process is disrupted, and the quality of processing is sharply reduced. In addition, when testing non-shaft rippers with passive working bodies, several shortcomings in their work were revealed, which manifested themselves to varying degrees in different soil conditions: when working in fields with plant residues, there is frequent clogging of the tool; when processing soils with low humidity and an over-compacted upper layer, a large number of large blocks are formed; on old-arable, waterlogged soils, the soil is often unloaded in front of the working bodies, which leads to their clogging.

\footnotetext{
* Corresponding author: sherxuja@mail.ru
} 
One of the ways to solve this problem is the use of active working bodies on tillage machines with passive working bodies, which, along with technological functions, will also perform the functions of movers and thereby relieve a narrow link in the chain of energy transmission through the tractor's mover, and will also contribute to improving the productivity and efficiency of the unit [28-31].

This work aims to substantiate the effectiveness of the use of an active working body on a front plow.

\section{Methods}

The object of research is a frontal plow with passive and active working bodies. The study of the technological processes of the combined front plow was carried out in laboratory and field conditions, according to literature sources, patents, and test results of the developed machine. The research was carried out on the stubble of winter wheat from under the grain at the experimental site of the Research Institute of Mechanization and Electrification of Agriculture (NIMESH). The type of soil is light serozem. The hardness and moisture content of the soil along the horizons of $0-10,10-20,2-30 \mathrm{~cm}$ was 2,$8 ; 3,51 ; 4,46 \mathrm{MPa}$ and 8,$1 ; 10,4 ; 12,8 \%$. The number of crop residues was $0,984 \mathrm{~kg} / \mathrm{m}^{2}$. When determining the quality indicators of the plow, we were guided by the program and methodology for testing agricultural machines according to Tst 63.02.2001 "Testing of agricultural machinery. Machines and tools for deep tillage. Program and test methods".

\section{Results and Discussion}

The authors developed a front plow with active and passive working bodies (Fig.1), which consists of an active working body 1, passive left - and-right-turning bodies 2 and 3 with hoods 4 . The active working body 1 receives a drive from the tractor power take-off shaft.

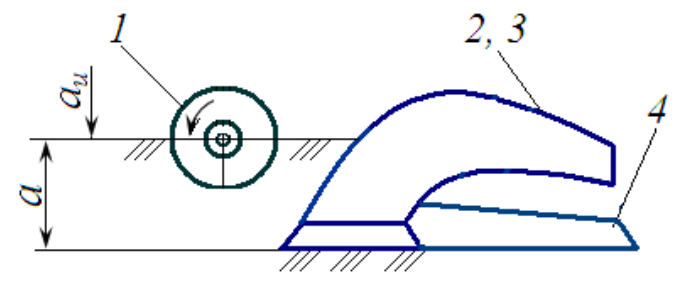

Fig. 1. Diagram of the front plow with active and passive working bodies: 1 is active working body; 2 and 3 are passive left and right-turning bodies; 4 is plowman

We analyze the forces acting on its working organs to identify the disadvantages and advantages of a combined frontal plug with a passive and active working body. Fig. 2 shows a diagram of the forces acting on a combined frontal plug with a passive and active working body [28].

For stable operation of the combined frontal plug in the longitudinal-vertical plane (without exiting the ground in the vertical direction), the following condition (in general view) for the general normal reaction of the soil on its support wheels must be fulfilled [29].

$$
\bar{N}=\bar{G}_{1}-\bar{P}_{z}+\bar{R}_{p z}-\bar{R}_{a z}-\bar{R}_{k z}-\bar{F}_{n}>0
$$


in this $\bar{N}$ is the total normal reaction force of the soil on the plug base wheels, $H$; $\bar{G}_{1}$ is the gravitational force of a combined frontal plug with a passive and active working body, $N$; $\bar{P}_{z}$ is the vertical component of the tractor traction force placed on the center of rotation of the plug, $N ; \bar{R}_{k z}$ is the vertical component of the force exerted by it on the plug at the point of connection of the roller to the frame, $H ; \bar{P}_{p z}$ is the vertical component of the ground resistance force acting on the bodies and zaplujnik of the plug, $N ; \bar{R}_{a z}$ is the vertical component of the soil resistance force acting on the active working body, $N ; \bar{F}_{n}$ is the vertical force acting on the frame by the roller pressure spring, $N$.

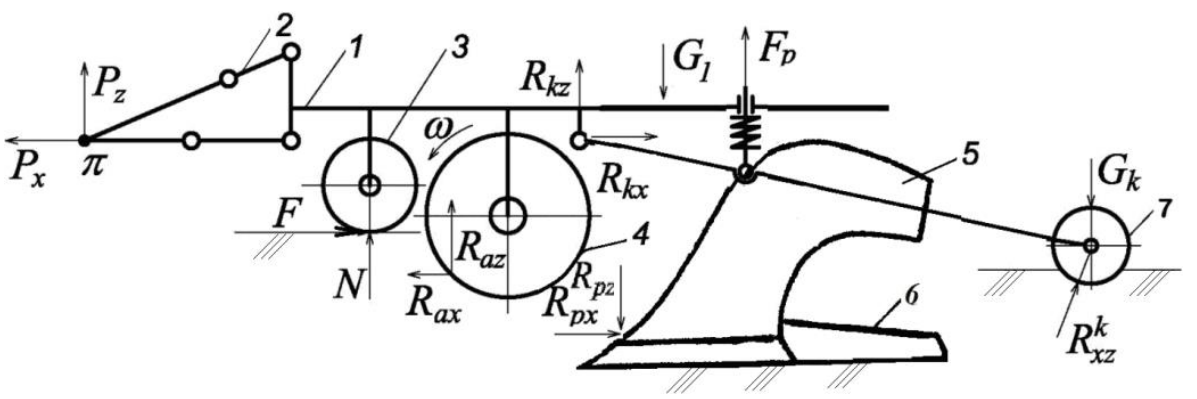

Fig. 2. Scheme of forces acting on the combined frontal plug with active and passive working body: 1 is frame; 2 tractor suspension; 3 isbase wheel; 4 is active working body; 5 is corpus; 6 is plowman; 7 is roller coaster

During the stable operation of the plow, the force $N$ must have its positive value, otherwise, it will come out of the ground, i.e., the working depth will be reduced. The smaller this force, the smaller the loss $\mathrm{F}$ to move the plug. (where $F=f N ; f-$ is the coefficient of resistance to rolling).

(2.1) It can be seen from the expression that the value of $N$ in a passive working organ plug is positive. To overcome $N$ force, a gravitational force with a large value must be applied. The base wheels of such a plug operate under severe conditions [28-31].

We do not consider the force $\mathrm{N}$, which can occur when the share blades do not pass, negatively value. In active working bodies, $R_{a z}$ is sometimes greater than the value of $G_{1}$, so it often does not sink deep enough into the soil, especially when working at great depths. Installing active and passive working bodies on the plug allows you to take advantage of their advantages. The $N$ force is mainly balanced by the $G_{1}$ and $R_{a z}$ forces. The difference between them and the $R_{p z}$ force creates a small normal load on the base wheels, ensuring the machine's continuous smooth running at the same machining depth [28-31].

To analyze the operation of the combined frontal plug in the longitudinal-vertical plane (in the horizontal direction), we construct the equation of equilibrium in the general view of the forces acting. The horizontal component of the tractor traction force acting on the instantaneous center of rotation of the plow suspended on the tractor

$$
\bar{P}_{x}=\bar{F}+\bar{R}_{p x}+\bar{R}_{k x}-\bar{R}_{a x},
$$

where and are the horizontal components of the ground resistance voltage acting on the plug's passive and active working bodies. To overcome the $R_{p x}$ and $F$ forces occurring during the passive working organ plow operation, it is necessary to create a very large force 
at the point of traction of the tractor, which leads to an increase in its weight.

Only during the operation of active working organ plugs $R_{a x}$ force can sometimes be greater than the $R_{x}$ force required to move the plug, which leads to negative shattering. The $R_{p x}$ and $R_{a x}$ forces that occur when active and passive working bodies are mounted on the plug balance each other to one degree or another and therefore, less gravitational force is required to pull the plug. All this ensures the stable operation of such an aggregate [28-31, 35-36].

Thus, it is advisable to use a combined frontal plow with the active and passive working body with high-powered tractors because it is efficient, does not require too much traction during operation, stability is at the required level (does not protrude from the ground, the normal reaction to base wheels is small).

In the tests, the kinematic operating mode of the active working body was set at 2.1, and the processing depth was set at $12.5 \mathrm{~cm}$. The results of the comparison tests are given in Table 1.

Table 1. Results of experimental studies of active and passive working organ device

\begin{tabular}{|c|c|c|}
\hline \multirow{2}{*}{ Name of indicators } & \multicolumn{2}{|c|}{ Two-body laboratory-field device } \\
\cline { 2 - 3 } & $\begin{array}{c}\text { Passive } \\
\text { working organ }\end{array}$ & $\begin{array}{c}\text { Active working } \\
\text { organ }\end{array}$ \\
\hline Movement speed, m/s & 1.94 & 2.16 \\
\hline Driving depth, cm & 28 & 24.3 \\
\hline Coefficient of variation of driving depth, \% & 6.34 & 6.63 \\
\hline Coverage width, cm & 105.8 & 106.2 \\
\hline Coefficient of coverage width variation, \% & 2.65 & 2.72 \\
\hline Roughness of plowed surface, cm & 6.4 & 5.5 \\
\hline Complete burial of plant debris, \% & 85.3 & 93.6 \\
\hline Depth of burial of plant remains, cm & 10.9 & 12.3 \\
\hline Soil erosion rate, \% & 75.4 & 83.9 \\
\hline Specific drag resistance of the device and the plug, & 71.4 & 60.9 \\
\hline kPa & & 5.44 \\
\hline Gravitational variation coefficient, \% & 7.61 & 6.4 \\
\hline Required power in the tractor KOV, $\mathrm{kW}$ & - & 28.19 \\
\hline Required power, $\mathrm{kW}$ & 23.9 & 26.54 \\
\hline Specific energy capacity, $\mathrm{kWh} / \mathrm{ha}$ & 25.1 & 27.56 \\
\hline Specific fuel consumption, $\mathrm{kg} / \mathrm{ha}$ & 33.29 & \\
\hline
\end{tabular}

The analysis of the obtained results shows that the installation of active working bodies in the form of milling machines in front of the tillage plows with $180 \%$ tillage within the boundaries of the owner increases soil compaction by $8,5 \%$, plant residue burial by $8.3 \%$, reduces ridge height by $0.9 \mathrm{~cm}$. The active working bodies had almost no effect on the movement stability of the device.

According to the experiments (Table 3.7), the specific gravity resistance of the active working body decreased by $14,7 \%$ compared to the passive working body, and the coefficient of variation of gravity resistance decreased by 1,40 times. Due to the decrease in traction resistance, the tractor's thrust decreased, and the operating speed increased from $1.94 \mathrm{~m} / \mathrm{s}$ to $2.16 \mathrm{~m} / \mathrm{s}$. The increase in traffic speed allowed to increase productivity by $11,3 \%$. At the same time, specific fuel consumption decreased by $17.2 \%$.

The active working frontal plug has an advantage over the passive working frontal plug in all aspects of the work process. Thus, the application of active working bodies and performing the driving function ensures the improvement of the working quality and energy performance of the plug in soils with low humidity and high density of the surface layer. 


\section{Conclusions}

1. The use of active working bodies, which perform in addition to technological and propulsion functions, improves the quality of work and energy indicators of the front plow and contributes to the effective use of energy-saturated tractors.

2. The use of an active working body on the front plow increases the degree of soil crumbling by $8.5 \%$, reduces the traction resistance and specific fuel consumption by $14.7 \%$ and $17.2 \%$, respectively, and increases the productivity of the unit by $11.3 \%$.

\section{References}

1. Mamatov, F.M., Eshdavlatov, E., Suyunov, A. The Shape of the Mixing Chamber of the Continuous Mixer // Jour of Adv Research in Dynamical \& Control Systems, Vol. 12, 07-Special Issue, 2020. DOI: 10.5373/JARDCS/V12SP7/20202318 ISSN 1943$023 \mathrm{X}$.

2. Mamatov, F., Ergashev, I., Ochilov, S., Pardaev, X. Traction Resistance of Soil Submersibility Type "Paraplau" // Jour of Adv Research in Dynamical \& Control Systems, Vol.12, 07-Special Issue, 2020. DOI: 10.5373/JARDCS/V12SP7/20202336 ISSN1943-023X.

3. Aldoshin, N., Mamatov, F., Ismailov, I., Ergashov, G. Development of combined tillage tool for melon cultivation // 19th international scientific conference engineering for rural development Proceedings, Jelgava, 20.-22.05.2020. Volume 19. ISSN 16915976. DOI:10.22616/ERDev.2020.19.TF175.

4. Umurzakov, U., Mirzaev, B., Mamatov, F., Ravshanov, H., Kurbonov, S. A rationale of broach-plow's parameters of the ridge-stepped ploughing of slopes // XII International Scientific Conference on Agricultural Machinery Industry IOP Conf. Series: Earth and Environmental Science 403(2019) 012163 IOP Publishing doi:10.1088/1755-1315/403/1/012163.

5. Mirzaev, B., Mamatov, F., Chuyanov, D., Ravshanov, X., Shodmonov, G., Tavashov, $\mathrm{R}$ and Fayzullayev, X. Combined machine for preparing soil for cropping of melons and gourds // XII International Scientific Conference on Agricultural Machinery Industry. doi.org/10.1088/1755-1315/403/1/012158.

6. Mirzaev, B., Mamatov, F., Ergashev, I., Ravshanov, H., Mirzaxodjaev, Sh., Kurbanov, Sh., Kodirov, U and Ergashev, G. Effect of fragmentation and pacing at spot ploughing on dry soils // E3S Web of Conferences 97. doi.org/10.1051/e3sconf/201913501065.

7. Mamatov, F., Mirzaev, B., Shoumarova, M., Berdimuratov, P., Khodzhaev, D. Comb former parameters for a cotton seeder// International Journal of Engineering and Advanced Technology (IJEAT) Volume-9 Issue1 October/ DOI: 10.35940/ijeat.A2932.109119.

8. Mamatov, F., Mirzaev, B., Batirov, Z., Toshtemirov, S., Tursunov, O., Bobojonov, L. Justification of machine parameters for ridge forming with simultaneous application of fertilizers // CONMECHYDRO - 2020 IOP Conf. Series: Materials Science and Engineering 883(2020) 012165 IOP Publishing. doi:10.1088/1757899X/883/1/012165.

9. Mirzaev, B., Mamatov, F., Avazov, I., Mardonov, S. Technologies and technical means for anti-erosion differentiated soil treatment system// E3S Web of Conferences. doi.org/10.1051/e3sconf/20199705036.

10. Aldoshin, N., Didmanidze, O., Mirzayev, B., Mamatov, F. Harvesting of mixed crops by axial rotary combines // Proceeding of $7^{\text {th }}$ International Conference on Trends in Agricultural Engineering 2019. $17^{\text {th }}-20^{\text {th }}$ Prague, Czech Republic. - pp.20-26. September (2019) 
11. Mirzaev, B., Mamatov, F., Aldoshin, N and Amonov, M. Anti-erosion two-stage tillage by ripper// Proceeding of 7th International Conference on Trends in Agricultural Engineering 17th-20th. Prague, Czech Republic. - pp.391-396. September (2019).

12. Mirzaev, B., Mamatov, F., Ergashev, I., Islomov, Yo., Toshtemirov, B., Tursunov O. Restoring degraded rangelands in Uzbekistan // Procedia Environmental Science, № 6. - pp 395-404. (2019).

13. Uzakov, Z.U., Mamatov, F.M., Begulov, O. Implementation of object-oriented Programming technology in the one-dimensional oil displacement problem // International Conference on information Science and Communications Technologies: ICISCT 2019/0012008. Tashkent, Uzbekistan. INSPEC Accession Number: 19412491. DOI: 10.1109/ICISCT47635.2019.9012008.

14. Mamatov, F., Mirzaev, B., Berdimuratov, P., Turkmenov, Kh., Muratov, L., Eshchanova, G. The stability stroke of cotton seeder moulder // CONMECHYDRO 2020. IOP Conf. Series: Materials Science and Engineering 883 (2020) 012145 IOP Publishing. doi:10.1088/1757-899X/883/1/012145.

15. Mamatov, F., Mirzaev, B., Tursunov, O. A Justification of Broach-Plow's Parameters of the Ridge-Stepped Ploughing // E3S Web of Conferences 97, 05035 (2019). doi.org/10.1051/e3sconf/20199705035.

16. Ahmedov, B.J., Mirzaev, B.S.,Mamatov, F.M., Khodzhaev, D.A., Julliev, M.K. Integrating of gis and gps for ionospheric perturbations in d- And f-layers using vlf receiver // InterCarto, InterGIS 26, - c. 547-560. DOI: 10.35595/2414-9179-2020-1-26547-560.

17. Mamatov, F., Mirzaev, B., Tursunov, O., Ochilov, S and Chorieva, D. Relief, physicomechanical and technological properties of soil in the cotton growing area // ICECAE 2020. IOP Conf. Series: Earth and Environmental Science 614(2020) 012169. IOP Publishing. doi:10.1088/1755-1315/614/1/012169.

18. Shamsutdinov, Z., Ubaydullaev, Sh., Shamsutdinov, N., Mirzaev, B., Mamatov, F., and Chorshabiyev, N. The concept of the phytogenic field: theory, research experience and practical significance // ICECAE 2020. IOP Conf. Series: Earth and Environmental Science 614(2020) 012164. IOP Publishing. doi:10.1088/1755-1315/614/1/012164.

19. Umurzakov, U., Mamatov, F., Aldoshin, N., and Mirzaev, B. Exploration of tillage technologies in the Republic of Uzbekistan // ICECAE 2020 IOP Conf. Series: Earth and Environmental Science 614(2020) 012168. IOP Publishing. doi:10.1088/17551315/614/1/012168.

20. Mamatov, F., Aldoshin, N., Mirzaev, B., Ravshanov, H., Kurbanov, Sh and Rashidov, N. Development of a frontal plow for smooth, furless plowing with cutoffs // IPICSE 2020. IOP Conf. Series: Materials Science and Engineering 1030 (2021) 012135 IOP Publishing. doi:10.1088/1757-899X/1030/1/012135.

21. Mamatov, F., Mirzaev, B., Mirzahodzhaev, Sh., Uzakov, Z and Choriyeva, D. Development of a front plow with active and passive working bodies // IPICSE 2020. IOP Conf. Series: Materials Science and Engineering 1030 (2021) 012164. IOP Publishing. doi:10.1088/1757-899X/1030/1/012164.

22. Mamato, F.M., Eshdavlatov, E., Suyuno, A. Continuous Feed Mixer Performance //Journal of Advanced Research in Dynamical and Control Systems (JARDCS). Volume-12, 07-Spesia1 Issue, 2020. DOI: 10.5373/JARDCS/V12SP7/20202343. ISSN 1943-023X.

23. Mamatov, F., Ergashev, I., Mirzaev, B., Pardaev, X, Chorieva, D. Research of the Penetration Process of the Frontal Plow // 2nd Bukittinggi International Conference on Education (BICED) 2020. Journal of Physics: Conference Series 1779 (2021) 012002. IOP Publishing. doi:10.1088/1742-6596/1779/1/012002. 
24. Kodirov, U., Aldoshin, N., Ubaydullayev, Sh., Sharipov, E., Muqimov, Z and Tulaganov, B. The soil preparation machine for seeding potatoes on comb // CONMECHYDRO - 2020 IOP Conf. Series: Materials Science and Engineering 883(2020) 012143 IOP Publishing doi:10.1088/1757-899X/883/1/012143.

25. Ravshanov, Kh., Fayzullaev, Kh., Ismoilov, I., Irgashev, D., Mamatov, S. The machine for the preparation of the soil in sowing of plow crops under film // CONMECHYDRO - 2020 IOP Conf. Series: Materials Science and Engineering 883(2020) 012138 IOP Publishing doi:10.1088/1757-899X/883/1/012138.

26. Ravshanov, H, Babajanov, L, Kuziev, Sh, Rashidov, N, Kurbanov, Sh. Plough hitch parameters for smooth tails// CONMECHYDRO - 2020 IOP Conf. Series: Materials Science and Engineering 883(2020) 012139 IOP Publishing doi:10.1088/1757899X/883/1/012139.

27. Chuyanov, D., Shodmonov, G.,Avazov, I., Rashidov, N, Ochilov, S. Soil preparation machine parameters for the cultivation of cucurbitaceous crops // CONMECHYDRO - (2020) IOP Conf. Series: Materials Science and Engineering 883(2020) 012139 IOP Publishing doi:10.1088/1757-899X/883/1/012122.

28. Mamatov F.M., Mirzaev B.S., Avazov I.Zh.. Agrotehnicheskie osnovy sozdanija protivojerozionnyh vlagosberegajushhih tehnicheskih sredstv obrabotki pochvy $\mathrm{v}$ uslovijah Uzbekistana // - Prirodoobustrojstvo, 2014. [In Russian].

29. Mamatov F.M., Mirzaev B.S. Erosion preventive technology of crested ladder-shaped tillage and plow design // European Applied Sciences.- pp. 71-73. Stuttgart (Germany), (2014).

30. Lobachevskij Ja.P., Mamatov F., Jergashev I.T. Frontal'nyj plug dlja hlopkovodstva // - Hlopok, № 6. - 35-37 str. [In Russian]. (1991).

31. Medvedev V.I. Jenergetika mashinnyh agregatov s rabochimi organami-dvizhiteljami. - Cheboksary: Chuvash. kn. izd-vo, [In Russian]. (1972).

32. Homenko M.S. i dr. Perspektivy ispol'zovanija pochvoobrabatyvajushhih mashin s aktivnymi i passivnymi rabochimi organami // Mehanizacija i jelektrifikacija sel'skogo hozjajstva. - №5 -1987-S.26-28. [In Russian].

33. Ahmetov A.A. Sozdanie kombinirovannoj mashiny $\mathrm{s}$ rotacionnymi rabochimi organami dlja predposevnoj obrabotki pochvy na zasolennyh zemljah: Diss. ...dokt. tehn. nauk.- 75 s. [In Russian]. - Tashkent, (2015).

34. Panov I.M. Vybor jenergosberegajushhih sposobov obrabotki pochvy // Traktory i sel'skohozjajstvennye mashiny. - №8 -1990- S.32-33. 1. Medvedev V.I. Jenergetika mashinnyh agregatov s rabochimi organami-dvizhiteljami. - Cheboksary: Chuvash. kn. izd-vo, [In Russian]. (1972).

35. Fayzullayev, Kh, Mamatov, S, Radjabov, M, Sharipov, Sh, Tavashov, R and Nurmanova, M. The quality of loosening the soil with subsoilers of the combined machine // IPICSE (2020). IOP Conf. Series: Materials Science and Engineering 1030 (2021) 012171.IOP Publishing. doi:10.1088/1757-899X/1030/1/012171.

36. Temirov, I, Ravshanov, Kh, Fayzullaev, Kh, Ubaydullaev, Sh and Kodirov, U. Development of a machine for preparing the soil for sowing melons under the film // IPICSE (2020). IOP Conf. Series: Materials Science and Engineering 1030 (2021) 012169. IOP Publishing. doi:10.1088/1757-899X/1030/1/012169. 